\title{
Energy Savings in an University Educational Building - the Case of Chemistry Building of Sapienza
}

\author{
Fabrizio Pini $^{1}$, Sara Verzari ${ }^{1}$, Alessia D'Angelo ${ }^{2}$ \\ ${ }^{1}$ CITERA Research Center, Sapienza University of Rome \\ Via Antonio Gramsci 53, 00197 Rome (Italy) \\ ${ }^{2}$ Department of Astronautics, Electrical, Energy Engineering, Sapienza University of Rome \\ Via Eudossiana 18, 00184 Rome, Italy \\ alessia.dangelo@uniroma1.it
}

\begin{abstract}
The commitment for sustainability is a target for the Sustainable Universities Network. Sapienza University of Rome goes in this direction through the energy refurbishment of its building stock, i.e. all the educational buildings. Sapienza campus was built in the 30's and it needs a coherent improvement in terms of energy and environmental performance. Conventional energy retrofitting measures must be within a prioritazion framework to effectively take the most cost-effective strategy. Here, the case of the Chemistry Faculty building is analysed considering the improvement of the building envelope in compliance with the architectural values to be preserved as well as the integration of renewable energy plant. A model of building was used to study it and to create the scenarios and their architectural impact. Furthermore, an energy analysis of the designed refurbishment was carried out to identify the savings.
\end{abstract}

Keywords: Existing buildings, Building physics, Energy refurbishment, Energy efficiency.

\section{Introduction}

The adoption of EU legislation in the field of energy and environment call for new urban life quality indices [1] together with more comprehensive building performance metrics [2] for both inland and coastal areas [3]. Building retrofit becomes a hot topic due to its potential to include innovative technologies [4] and comply with urban waste management [4] and energy planning [5]. Energy and environmental retrofit can be tricky in modern architecture [6] if connected to renewable integration [7] and prioritizing the measures is needed [8]. Pushing the adoption of cutting edge technologies at building and urban level [9] should be beneficial in terms of economic [10], environmental benefits [11], thermodynamics [12] and ICT management [13] but conventional and established approaches are often more feasible [14]. Yet, energy planning tools show innovative energy strategies [15] applicable at large environments [16] and involving satellite data [17] to promote a specific renewable energy such as solar [18] or wind [19]. University campuses are between a codified urban level and a building one, comparable with the neighbourhood scale [20] when retrofitting must be planned [21] or GIS tool become suitable [22]. Previous research in this field led to single building retrofitting approach [23] together with testing small scale devices [24], providing cost-benefit analysis [25] and using building performance modelling with in-situ measurements [26] and simplified dynamic tool [27].

Environmental performance is a topic faced from two points of views: environment as indoor and as surroundings. For the first one, comfort analysis and link with energy use is essential [28] while, a wider meaning related to the second point of view entails pollution control and correlation [29] and effects on resource mapping [30]. This paper presents the energy and environmental retrofitting design for a University building located in Rome, Italy. As part of the implementation plan of smart energy solutions by Sapienza University of Rome in its building stock, the study is related to the barriers to overcome when energy refurbishment is designed for historic buildings as well as part of a listed complex due to its architectural values. The University already dealt with energy system improvements [31] or the upgrade of the energy supply [32] when all the building components cannot be modified or even the interior design is listed and neither the heating terminals can be substituted [33]. And, at the same time, where available in other branches the most innovative solutions mapped in other areas [34] are replicated and tested [35]. From the experience of a previous University building refurbishment [36], it is noteworthy to combine single measures for the best mix in terms of energy efficiency, energy flexibility potential [37] and 
sustainability as well. Sapienza University belongs to the Sustainable Universities Network, committed for improving energy and environmental performance of the campus.

\section{Building and its history}

Chemistry building, one of the largest in the campus, is selected as case study. It was built in 1938 as part of the complex "Citta' Universitaria" as shown in Figure 1. The target of the Energy Masterplan for that portion of City is to have the so-called energy islands where each building interacts each other in terms of energy flows. This synergy [38] is foreseeable for existing and new buildings [39]. This novelty is beyond the selection of the best materials to retrofit a building even coping with constrained environment [40]. Indeed, more comprehensive analysis and metrics such as Life Cycle Analysis can be integrated to address multiple sustainability aspects [41].

The Chemistry building shows a regular and compact form together with a modular scan of the façade. This is suitable for replicable refurbishment design. Many interventions were already made during its lifespan to restore the injuries of the Second World War, to divide further rooms and adapt laboratories to safety regulations.

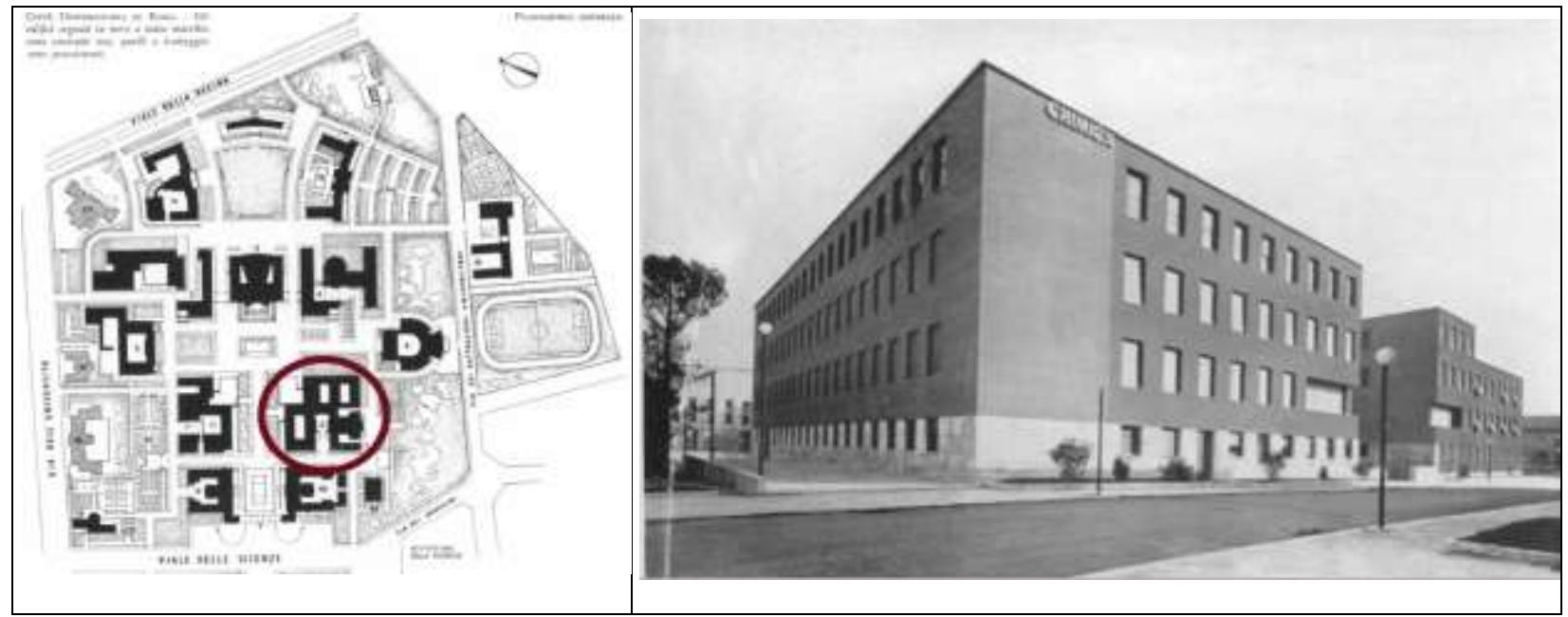

Fig. 1: a) Plan of Città Universitaria; b) Chemistry Building - picture of 1935.

In order to determine the performance of the building, components' stratification was analysed by means of architectural drawings, archive's material and in-situ surveys. Then, an abacus of wall, roof and floor structure was built along with the calculation of the equivalent U-value. It is reported in Figure 2.

In detail, the wall is made of three layers, two made of bricks where one is covered by stone and a cavity. While, the partitions are made of a single layer of pumice stone mix with good acoustic insulation. The floor structure is called "Varese" type, with a concrete beams and hollow flooring blocks.

Referring to the windows, they are present both in steel and wood frames. Those latter ones are the main part since wood is less sensitive to the vapour of the chemical reactions occurring in the laboratory rooms as well as no-reactive at magnetic forces. Steel windows are very large and step by step were substituted by aluminium ones.

Figure 3 shows the different mentioned types. 


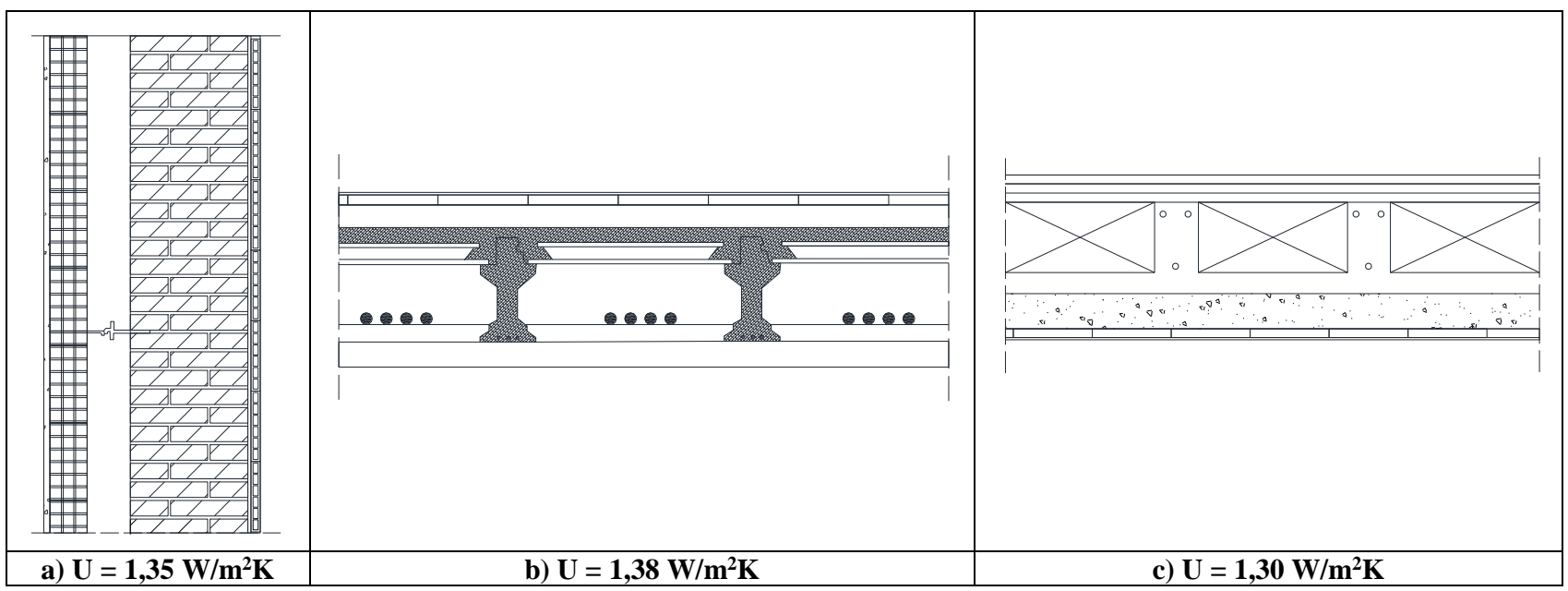

Fig. 2: Abacus of building envelope typologies and their wall construction.

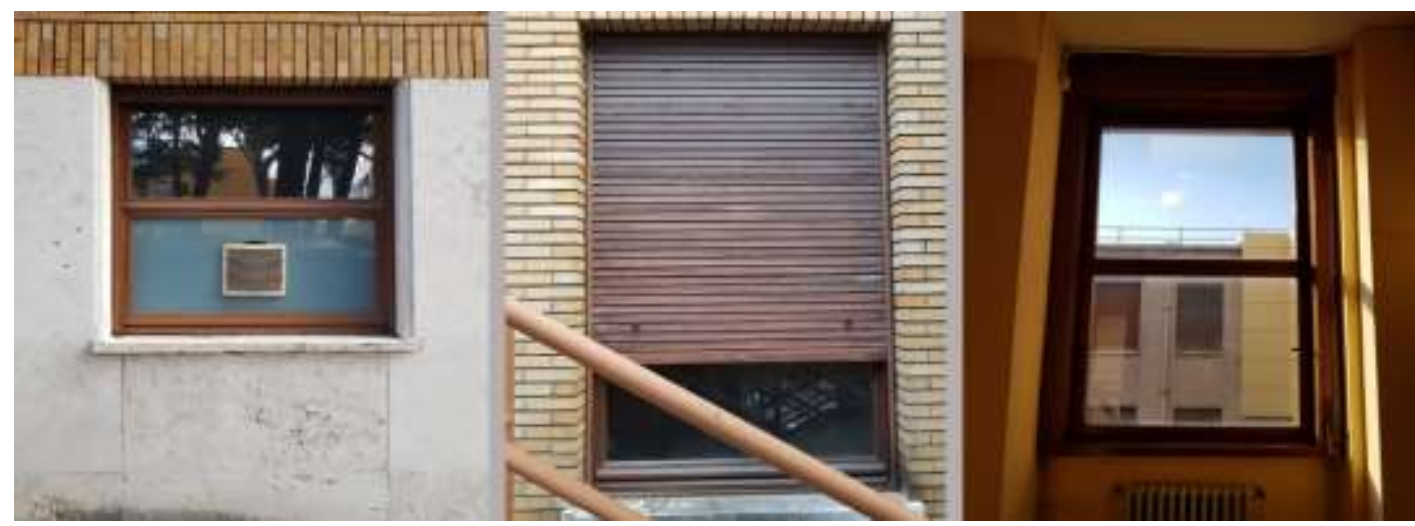

Fig. 3: Windows' typologies.

From an energy point of view, a district heating network is present, supplied by a centralized boiler with 15 MW of thermal power. The water produced by it reaches $130^{\circ} \mathrm{C}$. A thermal substation allows the connection between the building and the district heating pipe. Two heat exchangers of $450 \mathrm{~kW}$ are installed in it. Constant flow distribution system is there.

Heating terminals are radiators and fan-coils. The regulation system is not present. Cooling supply was not planned and splits with individual units were subsequently installed in the required rooms.

Furthermore, the Hot Water is locally produced in the toilets by installed electric heater. Based on this set of information, a model was built using Stima10-TFM software, which implements the procedures of the UNI 7357/74 for the calculation of winter thermal loads, the Transfer Function Method (TFM) ASHRAE for the calculation of summer thermal loads and calculations of UNI/TS 11300 (UNI EN ISO 13790 national adoption) for the final values of energy needs.

The building model was validated by comparison with the data from energy bills. The current situation is described by Table 1. According to energy label procedure, category D was identified since its fossil primary energy consumption is 99.7 $\mathrm{kWh} / \mathrm{m}^{2} \mathrm{y}$. The renewable fraction is around $10.5 \%$, calculated considering only the National energy mix from the Power Grid. The primary energy needed for heating purposes is $24.8 \mathrm{kWh} / \mathrm{m}^{2} \mathrm{y}$ while, the one for cooling purposes is $37.5 \mathrm{kWh} / \mathrm{m}^{2} \mathrm{y}$. Furthermore, the average seasonal efficiency of heating system is $48.5 \%$. 
Table 1: Primary energy consumptions.

\begin{tabular}{|l|c|c|c|c|c|c|}
\hline & & Heating & Cooling & Hot water & Lighting & Total \\
\hline Renewable & {$[\mathrm{kWh} / \mathrm{y}]$} & 0 & 35,288 & 703 & 177,938 & 213,929 \\
\hline Non-renewable & {$[\mathrm{kWh} / \mathrm{y}]$} & 937,323 & 146,507 & 2,919 & 738,747 & $1,825,496$ \\
\hline Total & {$[\mathrm{kWh} / \mathrm{y}]$} & 937,323 & 181,795 & 3,623 & 916,684 & $2,039,425$ \\
\hline Renewable fraction & $\%$ & $0.0 \%$ & $19.4 \%$ & $19.4 \%$ & $19.4 \%$ & $10.5 \%$ \\
\hline
\end{tabular}

\section{Retrofitting interventions}

Eco-architecture principles can be applied by using local materials [42] together with the analisys of renewable sources available to decarbonize the building supply [43]. Here, main interventions are related to the reduce energy consumption by means of lower U-values for each building component. Since the architectural values must be preserved since it is a listed building, insulation can be integrated in the cavity and not directly in the external façade, energy systems can be modified and the installation of new renewable plants can be done only on the roof. Further interventions possibly attacking this principles must be assessed by risk management matrix [44].

Previous research available for the Italian context provides guidelines for use of materials providing benefits in terms of energy savings [45]. Having said, the wall structure is improved by mean of inserting aerogel panels, a high performance material for tiny cavities. Pavement was further insulted by means of XPS rigid panels while, rock wool is applied to the roof structure to guarantee waterproofing. Finally, as regards the windows, single-glass windows were substituted with double-glass ones and low emissivity characteristics. Table 2 reports the values.

Table 2: U-value of building components.

\begin{tabular}{|l|c|c|}
\hline Description & Current situation & Proposed measure \\
\hline Vertical building envelope & $\mathrm{U}\left[\mathrm{W} / \mathrm{m}^{2} \mathrm{~K}\right]$ & $\mathrm{U}\left[\mathrm{W} / \mathrm{m}^{2} \mathrm{~K}\right]$ \\
\hline Ground floor & 1.25 & $0.67-0.73$ \\
\hline Roof & 1.39 & 1.25 \\
\hline Windows & $3.28-5.42$ & 1.39 \\
\hline
\end{tabular}

Referring to the energy system, a regulation system is the first measure to take to efficiently use the energy. Thus, heating terminals will be equipped with thermo-static valves. Then, the distribution system will be improved by allowing variable flow in the hydraulic loop. In terms of final use, the lamps will be changed with LED ones and the lighting control will be automatized as well.

As regards renewable energy sources, solar energy is the most suitable since the supply of the entire campus can be certified with sustainable biomass as studied in [46] to reduce the implications of this large impact decision [47]. So, on the roof a PV plants will be installed with 388 modules of $300 \mathrm{~W}$ for a total power of $116.4 \mathrm{kWp}$. The layout is shown in Figure 4. Considering all the proposed interventions, the achievable energy label is B, with a fossil primary energy equal to $54.6 \mathrm{kWh} / \mathrm{m}^{2} \mathrm{y}$, i.e. $-50 \%$, and with a renewable fraction of $20.9 \%$ deriving from the PV array and the National Grid contribution, as shown in Table 3. It allows reaching further energy flexibility level [48].

The primary energy needed for heating purposes is $8.8 \mathrm{kWh} / \mathrm{m}^{2} \mathrm{y}$ while, the one for cooling purposes is 36.3 $\mathrm{kWh} / \mathrm{m}^{2} \mathrm{y}$. Furthermore, the average seasonal efficiency of heating system is $60.4 \%$.

Table 3: Primary energy consumptions.

\begin{tabular}{|l|c|c|c|c|c|c|}
\hline & & Heating & Cooling & Hot water & Lighting & Total \\
\hline Renewable & {$[\mathrm{kWh} / \mathrm{y}]$} & 0 & 51,260 & 703 & 211,640 & 263,603 \\
\hline Non-renewable & {$[\mathrm{kWh} / \mathrm{y}]$} & 399,860 & 110,041 & 2,919 & 486,817 & 999,637 \\
\hline Total & {$[\mathrm{kWh} / \mathrm{y}]$} & 399,860 & 161,301 & 3,623 & 698,457 & $1,263,240$ \\
\hline Renewable fraction & $\%$ & $0.0 \%$ & $31,8 \%$ & $19.4 \%$ & $30,3 \%$ & $20.9 \%$ \\
\hline
\end{tabular}




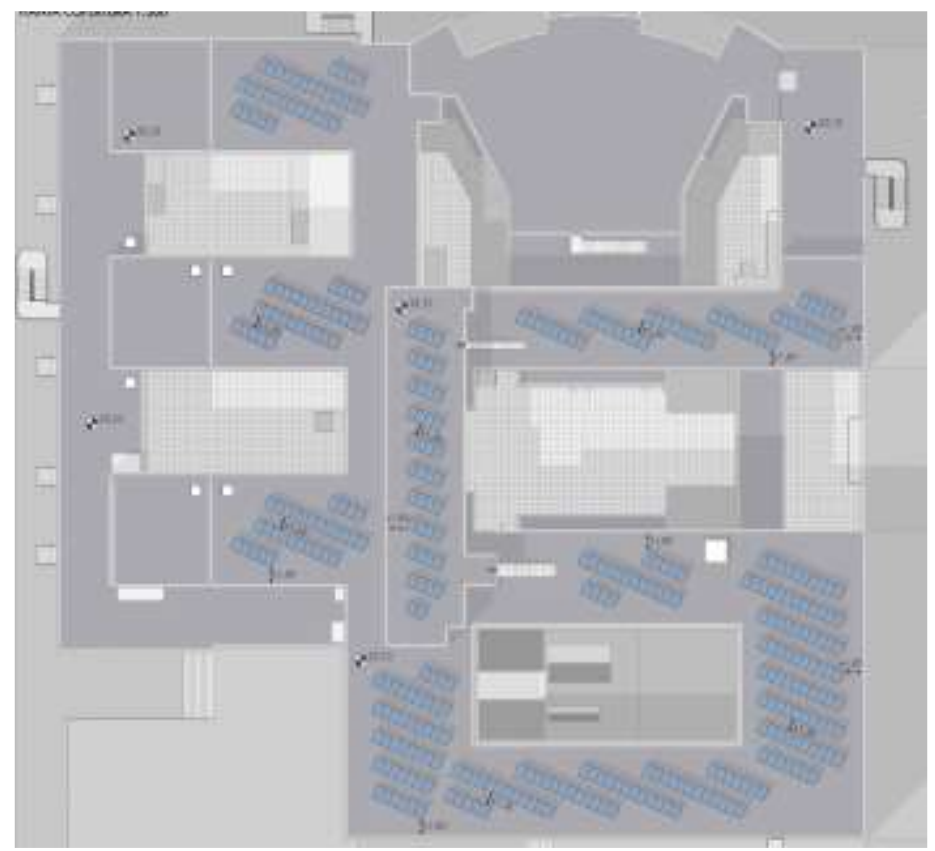

Fig. 4: layout of PV array location on the building roof.

\section{Conclusions}

An energy analysis of the Chemistry building was carried out to evaluate current performance and foreseeable values after the refurbishment. The interventions are designed on the building envelope, energy systems and renewable energy integration. Even in a constrained environment as a listed building, there are building technology solutions able to reduce energy consumption, make more efficient use of the available energy and possibility to install Photovoltaics to increase the renewable energy fraction of the consumptions. Within the framework of the Energy Masterplan for the Sapienza University Campus, each building is retrofitted and analysed to explore the reduction in energy use and the opportunities in energy production to contribute to a more sustainable building stock. This case study showed the methodology extended to the other buildings by tailoring the design to the peculiarities of each one.

\section{References}

[1] D. Astiaso Garcia, F. Cumo, E. Pennacchia, V. Stefanini, G. Piras, V. De Notti et al., "Assessment of a urban sustainability and life quality index for elderly", Int J of Sustain Develop Plan, vol. 12, no. 5, pp. 908-921, 2017.

[2] L. Tronchin, M. Manfren, V. Vodola and B. Nastasi, "Building performance monitoring: from in-situ measurement to regression-based approaches" Journal of Physics: Conference Series, 2019.

[3] F. Cumo, F.R. Curreli, E. Pennacchia, G. Piras and R. Roversi, "Enhancing the urban quality of life: A case study of a coastal city in the metropolitan area of Rome", WIT Trans on the Built Environment, vol. 170, pp. 127-137, 2017.

[4] R. Roversi, F. Cumo, A. D’Angelo, E. Pennacchia and G. Piras, "Feasibility of municipal waste reuse for building envelopes for near zero-energy buildings", WIT Trans Ecology and the Environment, vol. 224, pp. 115-125, 2017.

[5] B. Nastasi, "Hydrogen Policy, Market and R\&D Projects" in Hydrogen Production from Solar Energy, F.Calise et al., Ed. Amsterdam: Elsevier, 2019.

[6] F. Mancini, S. Salvo and V. Piacentini, "Issues of Energy Retrofitting of a Modern Public Housing Estates: The 'Giorgio Morandi' Complex at Tor Sapienza, Rome, 1975-1979”, Energy Procedia, vol. 101, pp. 1111-1118, 2016.

[7] D. Groppi, L. de Santoli, F. Cumo and D. Astiaso Garcia, "A GIS-based model to assess buildings energy consumption and usable solar energy potential in urban areas", Sustainable Cities and Society, vol. 40, pp. 546-558, 2018.

[8] D. Astiaso Garcia, M. Amori, F. Giovanardi, G. Piras, D. Groppi, F. Cumo and L. de Santoli, "An Identification and 
a Prioritisation of Geographic and Temporal Data Gaps of Mediterranean Marine Databases." Science of the Total Environment, vol. 668, pp. 531-546, 2019.

[9] B. Nastasi, "Power to Gas and Hydrogen applications to energy systems at different scales - Building, District and National level" Int. J. of Hydrogen En., vol. 44, no. 19, pp. 9485, 2019.

[10] G.L. Zupone, M. Amelio, S. Barbarelli, G. Florio, N.M. Scornaienchi, and A. Cutrupi, "Levelized Cost of Energy: A First Evaluation for a Self Balancing Kinetic Turbine”, Energy Procedia, vol. 75, pp. 283-293, 2015.

[11] M. Marignani, D. Bruschi, D. Astiaso Garcia, R. Frondoni, E. Carli, M. S. Pinna et al. "Identification and prioritization of areas with high environmental risk in Mediterranean coastal areas: A flexible approach", Science of The Total Environment, vol. 590-591, pp. 566-578, 2017.

[12] L. de Santoli, G. Lo Basso, D. Astiaso Garcia, G. Piras and G. Spiridigliozzi, "Dynamic Simulation Model of TransCritical Carbon Dioxide Heat Pump Application for Boosting Low Temperature Distribution Networks in Dwellings", Energies vol. 12, 484, 2019.

[13] L. Tronchin, M. Manfren and B. Nastasi, "Energy analytics for supporting built environment decarbonisation" Energy Procedia, vol. 157, pp. 1486-1493, 2019.

[14] G. Piras, E. Pennacchia, F. Barbanera and F. Cinquepalmi, "The use of local materials for low-energy service buildings in touristic island: The case study of Favignana island", 17th EEEIC Proceedings, no. 7977496, 2017.

[15] B. Nastasi, G. Lo Basso, D.A. Garcia, F. Cumo and L. De Santoli, "Power-to-gas leverage effect on power-to-heat application for urban renewable thermal energy systems" Int. J. of Hydrogen En., vol. 43, pp. 23076-23090, 2018.

[16] G. Harik, I. Alameddine, R. Maroun, G. Rachid, D. Bruschi, D. Astiaso Garcia, M. El-Fadel, "Implications of adopting a biodiversity-based vulnerability index versus a shoreline environmental sensitivity index on management and policy planning along coastal areas", J of Env Manage, vol. 187, pp. 187-200, 2017.

[17] M. Majidi Nezhad, D. Groppi, G. Laneve, P. Marzialetti and G. Piras, "Oil Spill Detection Analyzing "Sentinel 2" Satellite Images: A Persian Gulf Case Study", World Congress on Civil, Structural, and Environmental Engineering, No. AWSPT 134, pp. 1-8, 2018.

[18] B. Nastasi and U. Di Matteo, "Solar Energy Technologies in Sustainable Energy Action Plans of Italian Big Cities", Energy Procedia, vol. 101, pp. 1064-1071.

[19] M. Majidi, D. Groppi, P. Marzialetti, L. Fusilli, G. Laneve, F. Cumo and D. Astiaso Garcia, "Wind energy potential analysis using Sentinel-1 satellite: A review and a case study on Mediterranean islands", Renewable and Sustainable Energy Reviews, vol. 109, pp. 499-513, 2019.

[20] F. Cumo, D. Astiaso Garcia, V. Stefanini and M. Tiberi, "Technologies and strategies to design sustainable tourist accommodations in areas of high environmental value not connected to the electricity grid" Int J of Sustain Dev Plan, vol. 10, pp. 20-28, 2015.

[21] L. De Santoli, F. Mancini, B. Nastasi and S. Ridolfi, "Energy retrofitting of dwellings from the 40's in Borgata Trullo - Rome" Energy Procedia, vol. 133, pp. 281-289, 2017.

[22] L. de Santoli, F. Mancini and D. Astiaso Garcia, "A GIS-based model to assess electric energy consumptions and usable renewable energy potential in Lazio region at municipality scale", Sustain Cit Soci, vol. 46, 101413, 2019.

[23] F. Mancini, C. Clemente, E. Carbonara, and S. Fraioli, "Energy and environmental retrofitting of the university building of Orthopaedic and Traumatological Clinic within Sapienza Città Universitaria", Energy Procedia, vol. 126, pp. 195-202, 2017.

[24] B. Castellani, E. Morini, B. Nastasi, A. Nicolini and F. Rossi, "Small-scale compressed air energy storage application for renewable energy integration in a listed building" Energies, vol. 11, no. 7, 1921, 2017.

[25] D. Astiaso Garcia, F. Cumo, M. Tiberi, V. Sforzini and G. Piras, "Cost-benefit analysis for energy management in public buildings: Four Italian case studies", Energies, vol. 9, no. 7, 2016.

[26] M. Manfren and B. Nastasi, "From in-situ measurement to regression and time series models: An overview of trends and prospects for building performance modelling" AIP Conference Proceedings, 2019.

[27] F. Mancini, M. Cecconi, F. De Sanctis and A. Beltotto, "Energy Retrofit of a Historic Building Using Simplified Dynamic Energy Modeling", Energy Procedia, vol. 101, pp. 1119-1126, 2016.

[28] M. Manfren, B. Nastasi, E.A. Piana and L. Tronchin, "On the link between Energy Performance of Building and Thermal Comfort: an example" AIP Conference Proceedings, vol. 11, no. 4, 872, 2019.

[29] G. Piras, F. Pini and D. Astiaso Garcia, "Correlations of PM10 concentrations in urban areas with vehicle fleet development, rain precipitation and diesel fuel sales", Atmospheric Pollution Research, 2019.

[30] M. Majidi, D. Groppi, P. Marzialetti, G. Piras and G. Laneve, " Mapping sea water surface in Persian Gulf, oil spill 
detection using Sentinal-1 images", World Congress on Civil, Structural, and Environmental Engineering, No. ICEPR 179, pp. 1-6, 2018.

[31] L. De Santoli, G. Lo Basso and B. Nastasi, "Innovative Hybrid CHP systems for high temperature heating plant in existing buildings" Energy Procedia, vol. 133, pp. 207-218, 2017.

[32] B. Castellani, S. Rinaldi, E. Morini, B. Nastasi, and F. Rossi, "Flue Gas Treatment by Power-to-Gas Integration for Methane and Ammonia Synthesis - Energy and Environmental Analysis.” Energy Conv Manage, vol. 171, pp 626634, 2018.

[33] B. Nastasi and U. Di Matteo, "Innovative Use of Hydrogen in Energy Retrofitting of Listed Buildings", Energy Procedia, vol. 111, pp. 435-441, 2017.

[34] M. Majidi Nezhad, D. Groppi, P. Marzialetti, G. Piras, " Nearshore wave energy assessment of Iranian coastlines", World Congress on Civil, Structural, and Environmental Engineering, No. ICEPR 180, pp. 1-6, 2018.

[35] M. Nezhad, D. Groppi, F. Rosa, G. Piras, F. Cumo and D. Astiaso Garcia, "Nearshore wave energy converters comparison and Mediterranean small island grid integration", Sustain Energy Tech Assess, vol. 30, pp. 68-76, 2018.

[36] L. De Santoli, F. Mancini, C. Clemente and S. Lucci, "Energy and technological refurbishment of the School of Architecture Valle Giulia, Rome", Energy Procedia, vol. 133, pp. 382-391, 2017.

[37] F. Mancini, G. Lo Basso and L. Santoli, "On the energy uses in residential buildings: characterisation for identifying flexible loads by means of a questionnaire survey", Energies, 2019.

[38] D. Groppi, D. Astiaso Garcia, G. Lo Basso and L. De Santoli, "Synergy between smart energy systems simulation tools for greening small Mediterranean islands", Renewable Energy, vol. 135, pp. 515-524, 2019.

[39] L. De Santoli, F. Mancini and S. Rossetti, "The energy sustainability of Palazzo Italia at EXPO 2015: Analysis of an nZEB building", Energy and Buildings, vol. 82, pp. 534-539, 2014.

[40] D.A. Garcia, U. Di Matteo and F. Cumo, "Selecting Eco-Friendly Thermal Systems for the Vittoriale Degli Italiani Historic Museum Building”, Sustainability, vol. 7, pp. 12615-12633, 2015.

[41] L. de Santoli, A. Sferra and G. Piras, "Life Cycle Assessment Of Electricity Generated By Photovoltaic Systems Manufactured In Europe And Installed In Buildings In The City Of Rome", WIT Trans Ecology Env, vol. 128, pp. 321-330, 2010.

[42] D. Astiaso Garcia, F. Cumo, F. Giustini, E. Pennacchia, A. M. Fogheri, "Eco-architecture And Sustainable Mobility: An Integrated Approach In Ladispoli Town", WIT Trans on The Built Env, vol. 142, pp. 59-68, 2014.

[43] B. Nastasi, "Renewable Hydrogen Potential for Low-carbon Retrofit of the Building Stocks", Energy Procedia, vol. 82, pp. 944-949, 2015.

[44] A. Al Shami, G. Harik, I. Alameddine, D. Bruschi, D. Astiaso Garcia and M. El-Fadel, "Risk assessment of oil spills along the Mediterranean coast: A sensitivity analysis of the choice of hazard quantification", Science of The Total Environment, vol. 574, pp. 234-245, 2017.

[45] F. Cumo, L. Calcagnini and G. Piras "Proposal For A Classification Method Of Building Materials In The Italian Rules Concerning Low Energy Design”, WIT Trans Ecology Env, vol. 102, pp. 6, 2007.

[46] D. Astiaso Garcia, S. Sangiorgio, F. Rosa, "Estimating the Potential Biomasses Energy Source of Forest and Agricultural Residues in the Cinque Terre Italian National Park", Energy Procedia, vol. 82, pp. 674-680, 2015.

[47] G. Harik, I. Alameddine, R. Maroun, G. Rachid, D. Bruschi, D. Astiaso Garcia and M. El-Fadel, "Implications of adopting a biodiversity-based vulnerability index versus a shoreline environmental sensitivity index on management and policy planning along coastal areas", J of Environmental Management, vol. 187, pp. 187-200, 2017.

[48] F. Mancini, and B. Nastasi, "Energy retrofitting effects on the energy flexibility of dwellings", Energies, 2019. 